\title{
綿繊維塊の圧縮クリープ挙動につけて
}

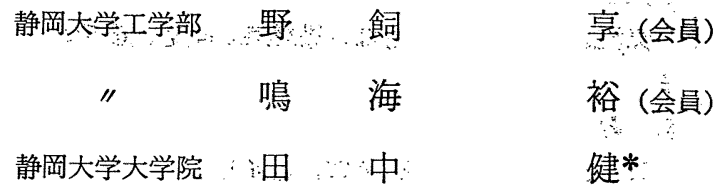

\section{A Study on the Compressive Creep Behaviour of Cotton Fiber Issemblies.}

\author{
Tooru Nogai, Yutaka Narumi and Ken Tanaka,
}

Faculty of Engineering,

Shizuoka University, Hamamatsu, Shizuoka Pref.

\begin{abstract}
As one step for establishment of a knowledge on the compressive rheological property of fiber assemblies, in this study, we investigated the compressive creep behaviour of cotton fiber assemblies, and the following conclusions were obtained :

(1) The compressive creep strain of cotton fiber assemblies increases with the increase of compressive load, and has the maximum value at the temperature $30 \sim 40^{\circ} \mathrm{C}$.

(2) The compressive creep property of the cotton fiber assemblies agrees with the creep expression obtained from the Eyring's non-linear three elements model.
\end{abstract}

(Received December 7,1974)

\section{摘 要}

目的塊状瀻維集合体の压縮粘弾性特性の解明の基礎的データを得るため, 綿瀻維塊を用いてその压縮クリ一 プ挙動を実験的に探求する.

成 果 （1）綿繊維塊を種々の荷重で压縮クリープさせるとき，任意経過時間での圧縮クリープひずみ（任

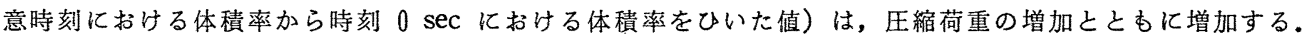

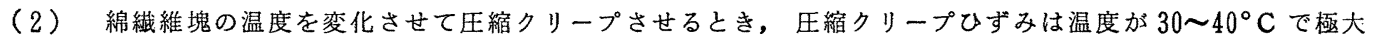
となる。

（3）綿䄉維塊の压縮クリープ曲線は, Eyring の非線形 3 要素モデルによるクリープの時間経過式と一致する. （昭和 49 年12月 7 日受理）

\section{1. まえがき}

繊維抢よび繊維集合体の力学的挙動は, 別報1),2) 飞示 されているように, 繊維工学の分野に执ててきわて重 要な問題である．そのため繊維の力学的性質に関しては 古くから多数の研究者たちによって探求され ${ }^{32,7)}$ ，その 結果繊維の力学的性質は非常に複雑な粘弾性挙動を示す てとが明らかにされた。しかしてのような複雑な力学的 挙動を示す綫維で構成されている繊維集合体に関して は, その構造上の複雑さに加えて取扱い上の困難さのた めに,かなり限定された材料や試験方法（たとえば糸,織
物9) カーペット ${ }^{8)}$ などのように形態が比較的安定してい る材料の引張, 圧縮, ねじりなど）に研究が集中し, 塊 状繊維集合体の圧縮応力緩和や圧縮クリープに関する研 究は 2,3 の研究者 2 (2),5) たちにとりあげられたにすぎ ず, 十分な特性の解明はなされていない.

本研究では上述の観点より, 従来あまり具体的にとり あげられていなかった綿䋐維塊の圧縮クリープ特性を， 荷重や温度を変化させた各種条件のもとで測定し, 綿緎 維塊の圧縮弾性特性を解明する基礎的データを得ること を目的とする。

2. 実 験 


\section{1 実験試料およびその調整法}

本研究で使用した瀻維材料は前報1),2) と同じ綿のカ一 ドあがりスライバ(平均緘維長 $30 \mathrm{~mm}$, 繊維直径 $2.2 \mathrm{~d}$, 密度 $1.54 \mathrm{~g} / \mathrm{cm}^{3}$ ) である. てれを従来と同様の方法 ${ }^{1)}$ で開瀻し,プラズチック円筒（内径 $80 \mathrm{~mm}$ ) に一定量 （本報では $5 \mathrm{~g}$ ）をできるだけ一様になるように詰める。 つぎにその上に直径 $78 \mathrm{~mm}$, 重さ $7 \mathrm{~g}$ の金属円板と $500 \mathrm{~g}$ の重鍾を載せ，常温で $30 \mathrm{~min}$ 放置する．そしてその後， 重鍾と円筒を抜き取るてとによってできる円柱状瀻維塊 が本研究における実験試料となる。

本研究ではさらに，各実験試料の開緘のばらつきを低 減させ, それ之同時认試料の温度を実験温度に近づける ために，つぎに述べる处理を行なう。

初めに前述の方法で調整された円柱状繊維塊を実験温 度に保たれている恒温槽内の圧縮円板上に載せ（図 1 参 照）, 試験荷重で $5 \mathrm{~min}$ 圧縮し，つぎに荷重を除いて $5 \mathrm{~min}$ 回復させる. この圧縮一回復操作を 3 回繰返す. この処理が終了した後，次節に述べる方法にしたがって 本測定を行なう。

\section{2 実験装置}

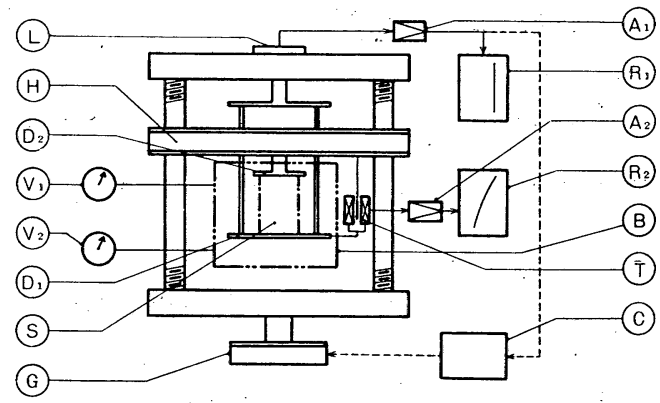

$\begin{array}{ll}A_{1}: \text { 荷重計測アンプ } & D_{1}, D_{2}: \text { 圧縮円板 } \\ R_{1}: \text { 荷重記録計 } & V_{1}, V_{2}: \text { 変圧器 } \\ A_{2}: \text { 変位計測アンプ } & G: \text { クロス ヘッド駆動装置 } \\ R_{2}: \text { 変位記録計 } & B: \text { 恒温槽 } \\ H: \text { クロス ヘット } & S: \text { 円柱状試料 } \\ C: \text { 自動負荷制御装置 } & L: \text { ロードセル } \\ T: \text { 差動トランス } & \end{array}$

\section{図 1 ”実験装置の模式図}

実験装置はオートグラフの機構を利用し，その概略が 図1亿示されている。こてで $L$ は荷重検出用ロードセ ル, $A_{1}$ は荷重計測アンプ, $R_{1}$ は荷重記録計, $T$ は差動 トランス, $A_{2}$ は変位計測アンプ, $R_{2}$ は変位記録計, $C$ は自動負荷制御装置, $H$ はクロス ヘッド， $G$ はクロ スヘッド駆動装置， $D_{1}$ および $D_{2}$ は圧縮円板， $B$ は 恒温槽, $V_{1}$ および $V_{2}$ はヒ一夕調節用変圧器である。 試料は圧縮円板 $D_{1}$ ¿ $D_{2}$ の間 $(S)$ 亿置か扎る。

\section{3 実験方法}

綿繊維塊の圧縮クリープ測定はつぎの手順にしたがっ
て行なわれる。

初めにクロス ヘッド $H$ に取付けられた圧縮円板 $D_{2}$ を $10 \mathrm{~mm} / \mathrm{min}$ の速度で降下させ, 圧縮円板 $D_{1}$ 上の試 料 $S$ を試験荷重まで圧縮し，同時にその試験荷重を一定 に保つように, 自動負荷制御装置 $C$ を作動させてクロ スヘッドの昇降を制御する。乙のクロス ヘッドの移 動を差動トランス $T$ で検出し, 变位記録計 $R_{2}$ に連続 的に記録させる．また荷重はロードセル $L$ で検出され， 荷重記録計 $R_{1}$ 亿記録される。

2.4 䋐維塊における圧縮クリープの定義

クリープ実験の場合, 一般の固体物質の引張クリープ におけるように，試料を瞬間的に負荷するととが理想的 である.しかし繊維塊の圧縮クリープのような場合には， 各種の制約により瞬間的に負荷することが困難であるた め, 2.3 で述べた過程にしたがって圧縮クリープの測定 を行なった。この場合, 繊維塊のクリープ状態はかなり あいまいなすのとなるが，本研究では圧縮クリープをつ ぎのように定義した。すなおち試料に加えられた荷重が 試験荷重の $98 \%$ に達した時刻を 0 sec とし, この瞬間 に織維塊はクリープ状態にはいり，乙れ以後の変形をク リープ変形と規定する。

また繊維塊のひずみについてあ，一般の固体物質のよ うに撖密な規定ができないため, 本研究では一般に使用 されるひずみ量のかわりに体積率（瀻維塊の見掛けの体 積に対する繊維の実体皘の割合）を用いる。したがって 前述の定義より, 繊維塊の圧縮クリープひずみは次式で 定義される：

$$
\varepsilon_{t}=\delta_{t}-\delta_{0}
$$

ててで $\varepsilon_{t}$ は時刻 $t \sec$ 亿おける圧縮クリープひずみ， $\delta_{t}$ および $\delta_{0}$ はそれぞれ時刻 $t$ sec および 0 sec 亿おける 繊維塊の体積率(本報では $\delta_{0}$ を瞬時体積率と呼称する) である，なお本報で用いた実験試料の体積率は, 綿の密 度 $1.54 \mathrm{~g} / \mathrm{cm}^{3}$, 試料の重量が $5 \mathrm{~g}$ であるから, 变位記 録計から読みとられる試料の時刻 $t \mathrm{sec}$ 亿扔ける高さ $h_{t}(\mathrm{~cm})$ を次式に代入することによって得られる：

$$
\delta_{t}=6.46 \times 10^{-2} \times h_{t}^{-1}
$$

したがって式(2)を式(1) に代入するととによって，圧 縮クリープひずみと高さの関係式が得られる：

$$
\varepsilon_{t}=6.46 \times 10^{-2}\left(\frac{1}{h_{t}}-\frac{1}{h_{0}}\right)
$$

ここで $h_{0}$ は時刻 $0 \mathrm{sec}$ における試料高さ $(\mathrm{cm})$ であ る.

しかし繊維集合体の圧縮クリープをより詳しく検討す るためには，任意時刻に㧍ける圧縮クリープひずみの絶 対量のみでなく，その時刻の圧縮クリープひずみと圧縮 ひずみの比率を知る必要がある，そてで本報では，次式 で定義される圧縮クリープひずみ率 $R_{\varepsilon}(\%)$ を考える：

$$
R_{\mathrm{s}}=\frac{\varepsilon_{t}}{\delta_{0}} \times 100=\left(\frac{\delta_{t}}{\delta_{0}}-1\right) \times 100
$$


式（3）に式（2）を代入するととによって次式が得られ る :

$$
R_{\varepsilon}=\left(\frac{h_{0}}{h_{t}}-1\right) \times 100 .
$$

\section{3. 結果および考察}

\section{1 実験結果}

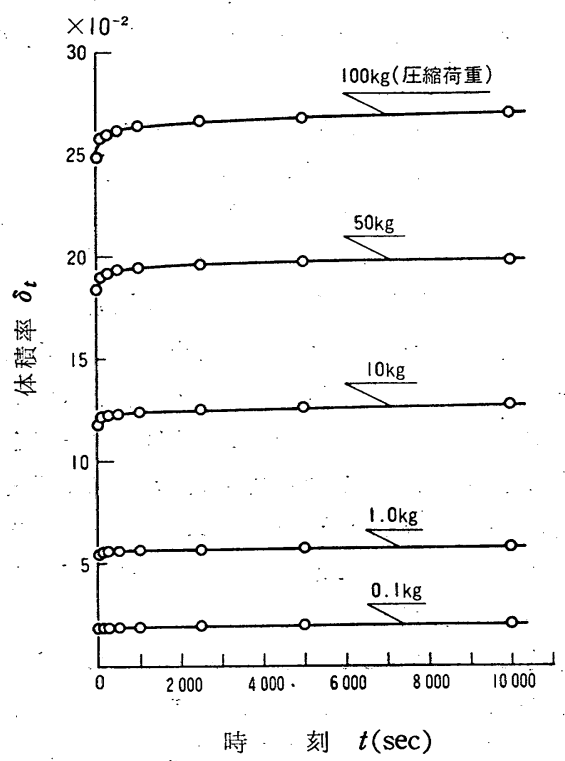

図2 測定結果例 (温度 $: 20^{\circ} \mathrm{C}$ )

2 で述べた実験方法にしたがって, 綿絾維塊の圧縮ク リープを各条件のもとで測定し，その結果の例を図 2 に 示す. 乙の図は温度 $20^{\circ} \mathrm{C}$ の各告縮荷重における測定結 果を示している。ここでデータの読取は, 記録計の精度

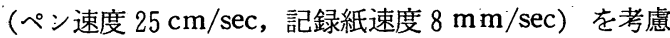
す机ば $0.2 \mathrm{sec}$ より可能であるが， $0 \mathrm{sec}$ のマーカがは いるため, $1 \mathrm{sec}$ より始めた。

図 2 亿示される綿繊維塊の庄縮クリープ曲線より, 綿 繊維塊の一定負荷に上る体積率の時間変動は圧縮荷重の 増加とともに大きくなる傾向を示す。また本研究におけ る他の温度条件で測定された圧縮クリープ曲線も, 図 2 认示される $20^{\circ} \mathrm{C}$. 場合と同様な特性を示している.

2.4 の定義にしたがって測定された瞬時体皘率 $\delta_{0}$ の

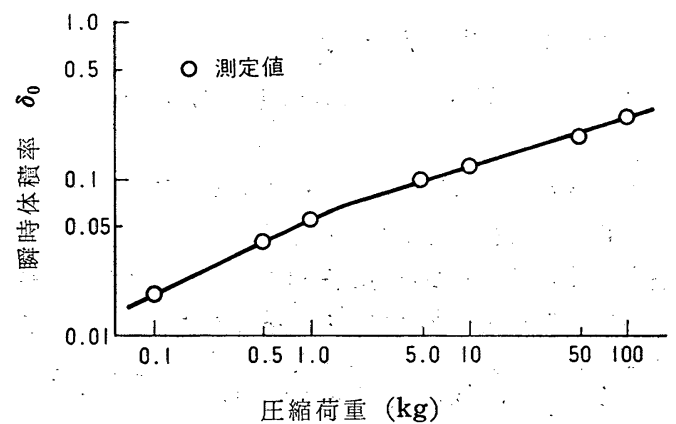

図 3 瞬時体積率之压縮荷重之の関係 (温度 $20^{\circ} \mathrm{C}$ )
例 $\left(20^{\circ} \mathrm{C}\right)$ を図 3 に示す. 乙の図より明らかなように， 瞬時体積率は圧縮荷重の増加にしたがって C.M.Van $\mathrm{Wyk}^{10)}$, 若山ら ${ }^{11)}$, ある(は前報)で得られているょう なべき関数的に大きくなる．またてのてとは，ほかの 温度条件の場合にも同じように現われる。

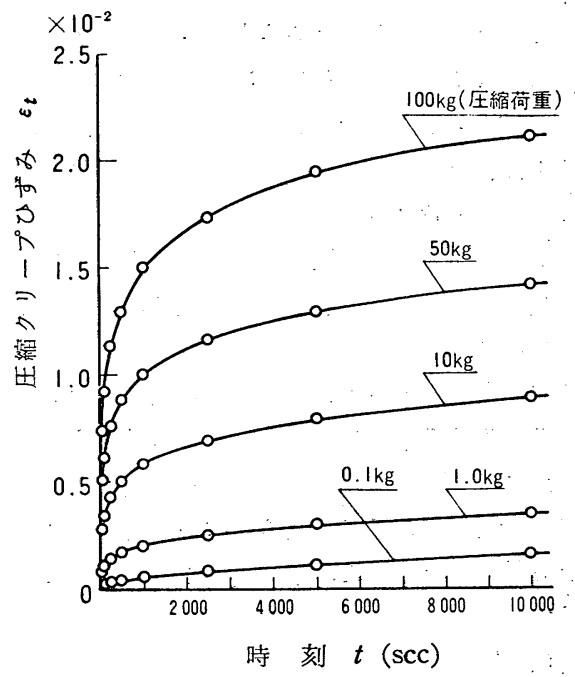

図4王縮クリープひずみの各压縮荷重における時間 変動 (温度 : $20^{\circ} \mathrm{C}$ )

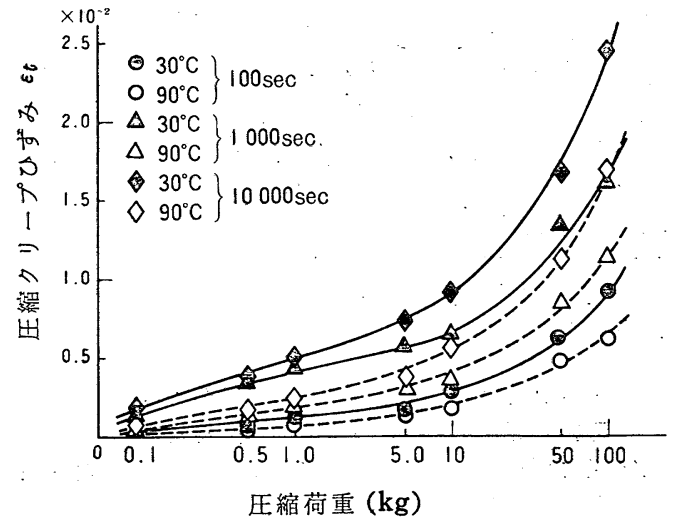

図 5 圧縮クリープひずみと压縮荷重との関係

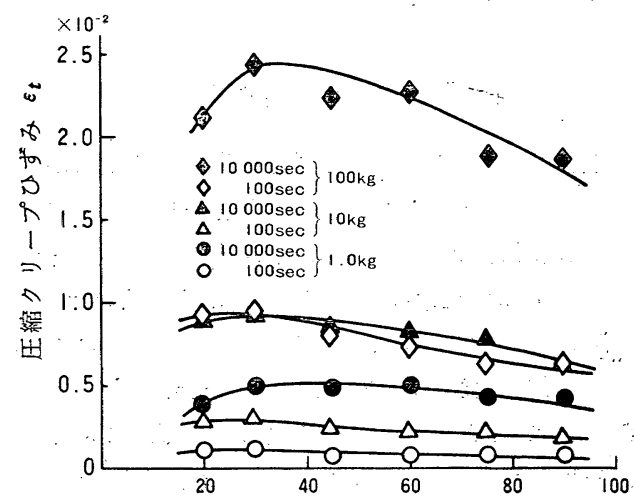

温 度 $\left({ }^{\circ} \mathrm{C}\right)$

因 6：圧縮クリープひずみと温度との関係 
綿繊維塊の圧縮クリープの測定結果（体皘率 $\delta_{t}$ ) から 瞬時体皘率 $\delta_{0}$ を差し引く乙とによって得られた綿繊維 塊の圧縮クリープひずみ $\varepsilon_{t}$ の計算例が図 4 図 6 に示 されている.乙こで図 4 は $20^{\circ} \mathrm{C}$ に打ける圧縮クリ一 プひずみ $\varepsilon_{t}$ の各圧縮荷重における時間変動を示し, 図 5 は各時刻における圧縮クリープひずみと圧縮荷重との 関係, 図 6 は各時刻における圧縮クリープひずみと温度 との関係を示している.

図 5 より明らかなように, 綿繊維塊の王縮クリープひ ずみは圧縮荷重の増加, すなわち瞬時体積率が高くなる ほど大きくなっている，また図 6 亿示されるように，い ずれの時刻, 荷重においても圧縮クリープひずみは温度 の上㫒ととあに増加し, $30 \sim 40^{\circ} \mathrm{C}$ を越えると逆に減少 している．乙の特性に関する物性的考察は本報の結果の みで進められないが, 前報2) で示した圧縮応力緩和の温 度依存性と比較すると, 応力緩和が $30 \sim 40^{\circ} \mathrm{C}$ で最大に なるととからあ, 繊維塊の圧縮における時間遅れ変形が この温度近辺で起りやすいてとが予想される。

.前述の実験結果を式 (3) 亿代入して得られた纴縮クリ

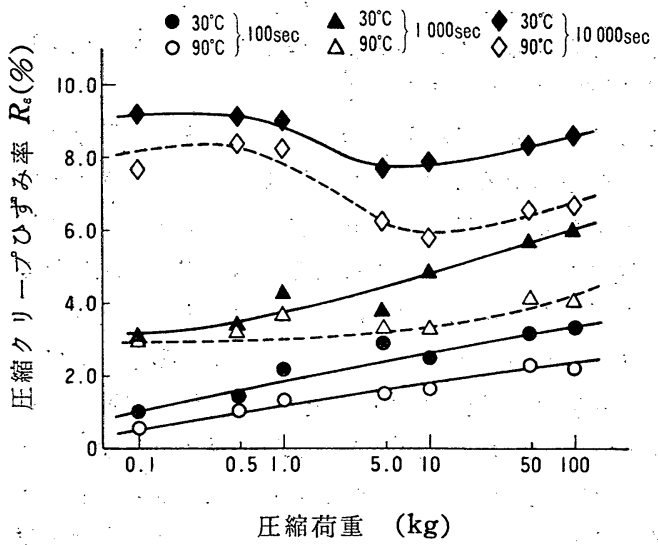

図 7. 珐縮クリープひずみ率と荷重との関係

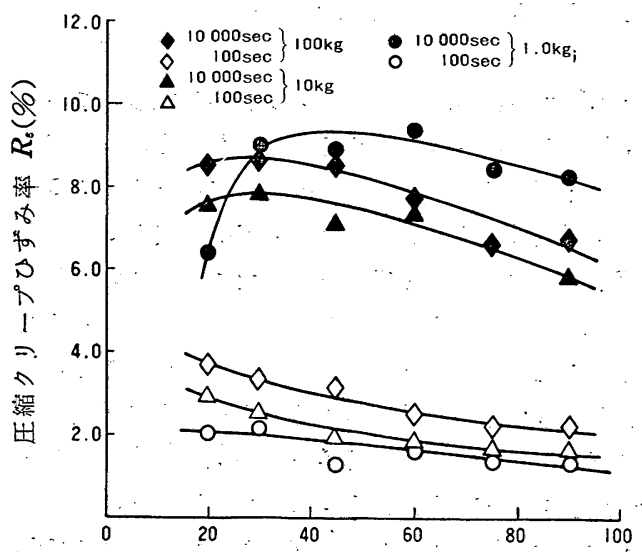

温度 $\left({ }^{\circ} \mathrm{C}\right)$

図 8 压縮クリープひずみ率と温度の関係
一プひずみ率 $R_{\varepsilon}$ の值を,図 7 および図 8 に示す.ここで 図 7 は圧縮クリープひずみ率 $R_{\varepsilon}$ と圧縮荷重との関係, 図 8 は圧縮クリープひずみ率と温度との関係を示してい る.

図 7 より明らかなように, 圧縮クリープひずみ率 $R_{8}$ は短時間側において, 圧縮荷重の増加とともに直線的に 大きくなる．乙れに対し長時間側においては，荷重 10 . $\mathrm{kg}$ 以上の場合に短時間側と同じ傾向を有するが, $10 \mathrm{~kg}$ 以下では反対の傾向，すなわち荷重の減少ととむに圧縮 クリープひずみ率が大きくなる．また図 8 より，長時間 側における王縮クリープひずみ率の温度依存性は王縮ク リープひずみの場合と定性的に一致し, $30 \sim 40^{\circ} \mathrm{C}$ 前後 に極大を持つ.しかし短時間側においては圧縮クリープ ひずみと異なり, 圧縮クリープひずみ率は温度の上昇と とすに低下している。

また荷重の相異による圧縮クリープひずみ率の温度変 化のちがいは，圧縮クリープひずみの場合と比べて小さ い. 式( 3 )からあわかるように, 圧縮クリープひずみ率 は瞬時体積率に反比例し, 生縮クリープひずみに正比例 するから,上述のことは両者の温度依存性が荷重の変化 によって相殺されると考えられる.

\section{2 考。察}

繊維集合体の圧縮特性の解析は, その構造上の複雑さ に加えて, 変形機構を実験的に観察する手段がないた め, 非常に困難である：そのため従来, 繊維集合体の構 造をモデル化(10) 13) し, そのモデル要素が弾性変形する と仮定した方法で解析が進められた。しかしいずれの解 析においても, 力之変形の静的な関係を解明しているす のであり，本報や前報2 に示している動的な関係，すな わち力あるいは変形の時間的変動にまでは解析を進めて いない.そこで本報では, 従来より圧縮特性の解析に使 用されている C.M.Van Wyk の弾性ばりモデルを用い て，綿繊維塊の圧縮クリープ特性を検討する.

本研究における実験試料の圧縮特性は瞬時体積率 $\delta_{0}$ を荷重に対してプロットした曲線(たとえば図 3 )と等価 である．したがって図 3 からあ明らかなように，瞬時体 積率は荷重の $1 / 3$ 乗にほぽ比例するから,本研究の綿瀻 維塊の圧縮特性は弾性ばりモデルによる理論式を満足す ると考えられる. それゆえ本研究の実験試料の構造モデ ルとして, C.M.Van Wyk モデル（以後モデル要素と 呼ぶ）を採用しても差支えないと考えられる。

モデル要素に $\Delta F$ の大きさの力が働いたとき，モデル 要素の弾性変形量を $\Delta y_{E}$ とし，また $\Delta F$ が加えられた 後 $t \sec$ だけ時間が経過したときのモデル要素のクリー プ変形量を $\Delta y_{c t}$ 亡する.と，モデル要素の全変形 $\Delta y_{t} *$ は

$$
\Delta y_{t}^{*}=\Delta y_{E}+\Delta y_{c t}
$$

で与えられる. $\Delta F$ が一定であるとすれば， $\Delta y_{E}$ は一定 で, $\Delta y_{c t}$ は時刻にようて決まり，乙れらは互いに独立 
である．それゆえてれら要素の変形の総和であると考え られる繊維塊の全変形 $y_{t}^{*}$ : は, 弾性变形成分 $\Delta y_{E}$ とク リープ変形成分 $\Delta y_{c t}$ のそれぞれの総和 $y_{E}$ および $y_{c t}$ の和であると考えられる：

$$
y_{t}{ }^{*}=y_{E}+y_{c t}
$$

こてで上式の右辺第 1 項は時刻に無関係であるから, 緎 維塊の圧縮クリープ変形は構成瀻維のクリープ变形のみ 亿依存する。

一般に各種単繊維のクリープ変形挙動は各種の力学モ デルや表示式で表わされているが, 綿䋐維についての測 定例はほとんど見出されない：そてでわれわれが以前に 測定した綿瀻維のクリリープ奋)を参考にすると, 綿瀻維の クリープは他のいくつかの繊維と同様に，いずれの試験 荷重あるいは温度に执いてす，10 104 sec の時間領域 でほぼ時間の対数に比例すると考えられる。したがって てのようなクリープ挙動は Eyring 粘性を示すダッシュ ポットを含む非線形 3 要素モデルで表わされると考えら れる. それゆえ任意時刻 $t$ 亿打计る単瀻維の変形を $r_{t}$ とすれば, 単䋐維のクリープ挙動は

$$
\dot{r}_{t}=r_{0}+Y \ln (u t+1)
$$

で表わされる．乙こで $\gamma_{0}$ は初期变形， $t$ は時刻 $(\mathrm{sec})$, $Y$ および $u$ は応力などによって決まる定数である．ま た上式の各項は式 (4)の各項に対応する.

したがって繊維の圧縮クリープ变形は式 ( 6 )にしたが う弾性ばりモデル要素のクリープ変形の総和であると考 えられる. このモデル要素のクリープ変形によって, 綿 䋐維は一定荷重を保持するように圧縮される，そして式 （2）上り，繊維塊の高さは一意的に体積率上対応するか 弓, 式 (6) 打打る $\gamma_{t}$ は体積率 $\delta_{t}$ 亿対応すると考え られる。それれえ式( 6 )上り, 綿繊維塊の圧縮クリープ は次式で表わされると考えられる：

$$
\delta_{t}=\delta_{0}+Y_{0} \ln (v t+1)
$$

ここで $Y_{0}$ および $v$ は定数である. 上式を式 (1) に代 入すると, 綿繊維塊の圧縮クリープひずみ $\varepsilon_{t}$ は

$$
\varepsilon_{t}=Y_{0} \ln \left(v_{t}+1\right)
$$

で表わされる.

3.1 の測定結果から式 $(8)$ の係数 $Y_{0}$ および $v$ を求 め, 式( 8 )に代入して計算した曲線を実験值ととあに図 9 亿示す. ててで図中の実線は式 (8) 亿よる計算曲線, 点線は実験曲線である.ただし $Y_{0}$ および $v$ の值は, $t=10^{3}$ および $10^{4}$ に扔ける $\varepsilon_{t}$ を式( 8 ) 亿代入し, 得ら れた 2 つの方程式を連立させて解くことによって求めら れた.

図9より明らかなように，短時間側において若干の相 違は見られるが，いずれの荷重あるいは温度においてす 計算曲線と実験曲線はほぼ一致していると考えられる。 したがって前述のように, 本研究で用いた綿繊維塊の圧 縮クリープ変形は, それを構成する単緘維のクリープ変

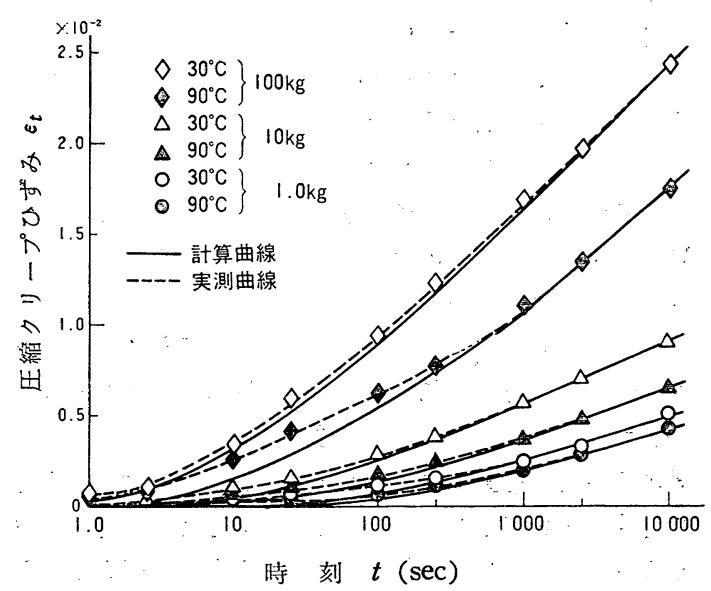

因 9“圧縮クリープひずみの実測值とモデルによる計 算值との比較

形にほぼ依存し,その挙動は非線形 3 要素モデルで表わ されると推定される。

図 9 亿预ける実験值と計算值の相違について考察する と, この原因として測定装置の精度の問題, 生縮クリ一 プびずみの定義, および構成繊維のクリープ以外の変形 機構の存在などが考えられる。

こてで測定装置の精度について考えてみる. 図 9 上り いずれの圧縮荷重においても実験值と計算值の差は同程 度であるから，誤差が生ずるとすれば，荷重検出部では なく変位検出部であると思われる. 本研究で使用した差 動トランスの感度は10（mv/mm） であるが, 精度はフ ル スケールの $1 \%$ であるから, 正確化読みとれる変位 の最小目盛は $0.01(\mathrm{~mm})$ である。しかし実験データ によると，10（sec）以上では試料の厚さの变化はほぼ $0.1(\mathrm{~mm})$ 以上（ただし測定条件により多少の変動は ある）であるから，10（sec）以上のデータは十分信頼 できる．したがって図 9 亿おける実験曲線之計算曲線の 相違は測定装置の 精度によるものではないと考えられ る.

つぎに綿繊維塊の圧縮クリープひずみの定義について 検討する. 乙の定義は 2.4 亿述べられたように，一般的 な瞬間負荷ではなく，必要荷重に到達するまでにある程 度の時間が経過している。したがって式( 6 )のようなも デル解とは条件的に異っている．またクリープ域におけ る圧縮の進行が試料を通したフィード バック制御であ るため, 測定されているクロスヘッドの移動にその制 御特性の影響があると考元られる。それゆえ本研究にお ける圧縮クリープひずみの定義および測定方法が, 図 9 の相違を生ずる一つの原因ではないかと考えられる。

綿䋐維塊の圧縮クリープが, 構成䋐維のクリープ変形 以外の変形機構にあ依存するかどうかについては，本報 のデータのみで断定することはできない。ただし図 7 お 
よび図 8 亿示される圧縮クリープひずみ率の荷重依存性 および温度依存性によれば，圧縮クリープひずみ率は低 荷重域(圧縮荷重 $1 \mathrm{~kg}$ 以下)之高荷重域 (10 kg 以上) で, その挙動が異なっていると考えられる. とくに 1000 sec 以上に执いてその相違が著しい. したがって, あし 構成繊維のクリープ変形以外の因子があるとすれば, 量 的にはそれほど大きくはないが，低荷重域ではかなりの 大きさを占めるような機構である。この機構代ういて断 言するでとはできないが，低荷重で生ずること妿ら，㵶 維之絾維の接触点のすべり,すなおち瀻維集合体の䋐維 の空間的配置の時間遅れ変化ではないかと予想される. しかしての機構は図 9 における挙動は説明できない.

以上のととから, 図 9 の実験值と計算值の相違仗, 本 研究に拉ける圧縮クリープひずみの定義による李のであ り変形機構代関する結論は得られない。

しかし綿繊維塊の圧縮クリープ挙動外,上述のように 非線形 3 要素モデルルよる計算值と若干の 相違はある が，全体的な傾向として非線形 3 要素モデル《よるクリ 一プ表示式で表わし得ると考えられる.

\section{4. まとめ}

綿繊維塊の圧縮クリープを各種条件のもとを゙測定した 結果,つつきの事項が明らかになった。

（1）綿繊維塊を種々の荷重で圧縮グータ゚させると き, 任意経過時間での圧縮クリープひずみは, 痤縮荷重 の増加ととあに增加する.

（2）綿瀻維塊の温度を変化させて圧縮クリープさせ
るとき，生縮クリープひずみは温度が $30^{\circ}$ ○ $40^{\circ} \mathrm{C}$ で極 大値をとる.

（3）綿瀻維塊の圧縮クリープ曲線は Eyring 粘性ダ ッシュ ポットを含む 3 要素モデルによるクリープの時 間経過式に一致する.

なお本研究の一部は日本繊維機械学会第27回年次大会 （昭和49年 6 月11日）で発表した。

\section{参考文献}

1)"野飼, 鳴海; 瀻機誌, 25, T 180 (1972)

2) “野飼; 鳴海, 田中; 瀻機誌, 27, T177（1974）

3) 1)および2)の参考文献

4) 松尾; 瀻学誌, 18, 474, 544, 551 (1962)

5) P.C.de Macarty, J.H.Dusenbury ; Text Res.J., 25, 875 (1955)

6）たとえば繊維学会編；繊維物理学，399，404 (丸善)

7）たとえば日本織維機械学会編；基礎瀻維工学 $[I]$, 53

8) 堀野, 三浦, 仲井; 絨機学会第, 27回年次大会講演 論文集, .93 (1974).

9):HBogaty"ほ加 3.名； Text.Res.J.23，168(1953)

10) C.M.Van Wyk ; J.Text-Inst:, 37, T.85 (1946)

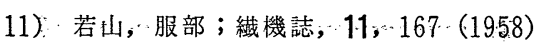

-12)? 嗵口; 清水; 瀻機誌, 13，850（1960)

13）松島, ·松尾；瀻学誌，16，105. (1960)

14)，野飼，鳴海; 未発表。 